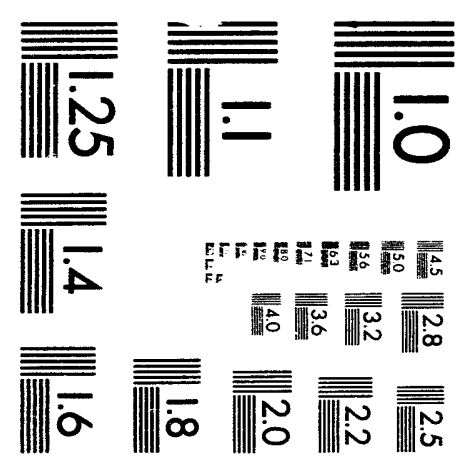



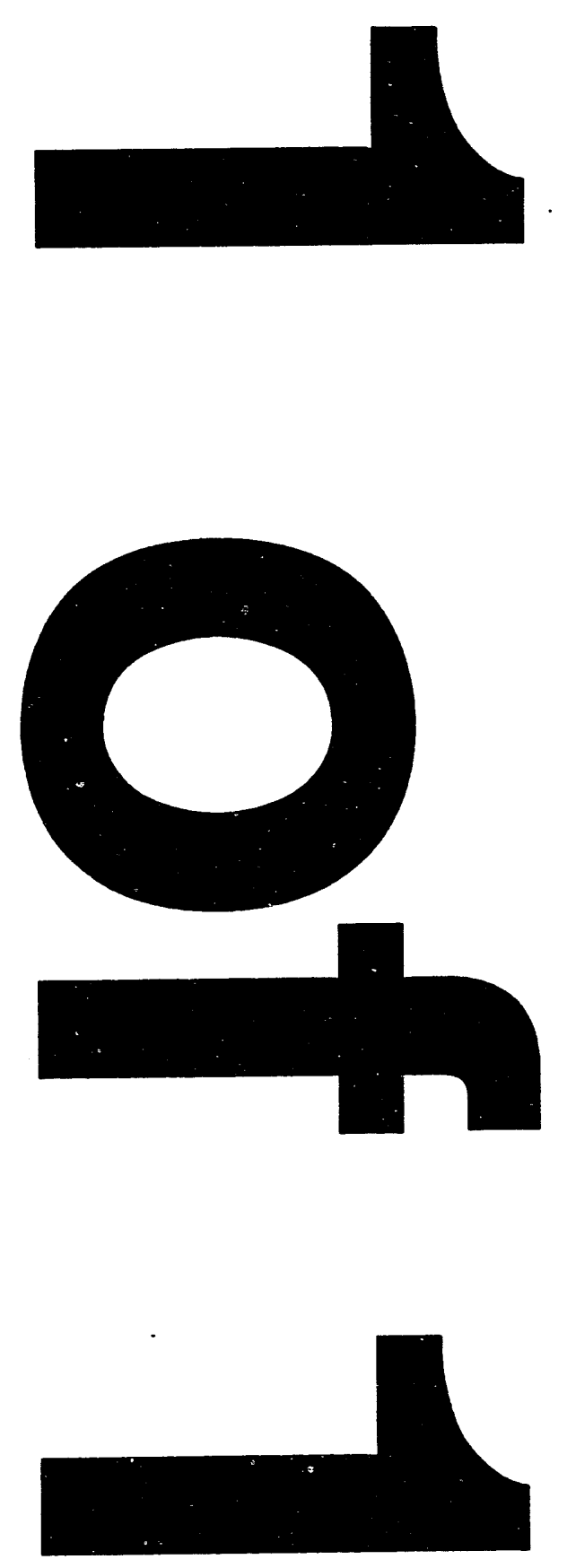


\title{
TASK PLAN: TEMPERATURES IN DWPF GLASS WASTE STORAGE BUILDING (U)
}

by

\author{
B. J. Hardy
}

Westinghouse Savannah River Company

Savannah River Site

Aiken, South Carolina 29808

DISCLAIMER

This report was prepared as an account of work sponsored by an agency of the United States Government. Neither the United States Government nor any agency thereof, nor any of their employees, makes any warranty, express or implied, or assumes any legal liability or responsibility for the accuracy, completeness, or usefulness of any information, apparatus, product, or process disclosed, or represents that its use would not infringe privatcly owned rights. Reference herein to any specific commercial product, process, or service by trade name, trademark, manufacturer, or otherwise does not necessarily constitute or imply its endorsement, recommendation, or favoring by the United States Government or any agency thereof. The views and opinions of authors expressed herein do not necessarily state or reflect those of the United States Government or any agency thereof.

DOE Contract No. DE-AC09-89SR18035

This paper was prepared in connection with work done under the above contract number with the U. S.

Department of Energy. By acceptance of this paper, the publisher and/or recipient acknowledges the U. S. Government's right to retain a nonexclusive, royalty-free license in and to any copyright covering this paper, along with the right to reproduce and to authorize others to reproduce all or part of the copyrighted paper.

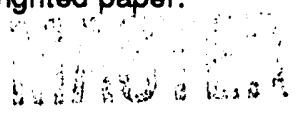




\section{DISCLAIMER}

This report was prepared as an account of work sponsored by an agency of the United States Government. Neither the United States Government nor any agency thereof, nor any of their employees, makes any warranty, express or implied, or assumes any legal liability or responsibility for the accuracy, completeness, or usefulness of any information, apparatus, product, or process disclosed, or represents that its use would not infringe privately owned rights. Reference herein to any specific commercial product, process, or service by trade name, trademark, manufacturer, or otherwise does not necessarily constitute or imply its endorsement, recommendation, or favoring by the United States Government or any agency thereof. The views and opinions of authors expressed herein do not necessarily state or reflect those of the United States Government or any agency thereof.

This report has been reproduced directly from the best available copy.

Available to DOE and DOE contractors from the Office of Scientific and Technical Information, P. O. Box 62, Oak Ridge, TN 37831; prices available from (615) 576-8401.

Available to the public from the National Technical Information Service, $U$. 5 . Department of Commerce, 5285 Port Royal Rd., Springfield, VA 22151 


\author{
WSRC-RP-93-1177 \\ REV. 0 \\ Keywords: GWSB Convection \\ GWSB Airflow \\ GWSB Concrete Temperature \\ DWPE Glass Temperature \\ Retention: Permanent
}

August 18,1993

TO: M. J. Plodinec, 773-A

S. L. Marra, 704-15S

EROM: B. J. Hardy, 773-64A B/ H

TASK PIAN: TEMPGRATURES IN DWRF GIASS WASTE STORAGE BUIIDING (U)

CC: E. W. Holtzscheiter, 773-A

J. R. Pelfrey, 773-42A

J. T. Carter, 704-25S

M. D. Boersma, 704-T

C. T. Randall, 704-T

F. J. Leach, 773-A

H. H. Elder, 704-S

A. A. Ramsey, 704-15S

G. J. Hutchens, 773-64A

J. W. Jerrel, 773-42A

N. E. Bibler, 773-A

J. E. Ortaldo, 704-S

J. A. Gentilucci, 704-S

L. E. Landon, 704-T

P. E. Lowe, 773-42A

W. T. Goldston, 704-S

J. F. Sproull, 704-S

S. J. Hensel, 773-42A

C. Payne, 704-24S

Technical Information Mangement, 703-43A 
WSRC-RP-93-1177

Revision 0

ce:
E. W. Holtzscheiter, 773-A
J. R. Pelfrey, 773-42A
J. T. Carter, 704-25S
M. D. Boersma, 7()4-T
C. T. Randall, 7()4-T
F. J. Leach, 773-A
H. H. Elder, 7()4-S
A. A. Ramsey, 7()4-15S
G. J. Hutchens, 773-64A
J. W. Jerrell, 773-42A

N. E. Bibler, 773-A

J. F. Ortaldo, 704-S

J. A. Gentilucci, 7()4-S

C. Payne, 704-24S

L. F. Landon, 704-T

P. E. Lowe, 773-42A

W. T. Goldston, 704-S

J. F. Sproull, 704-S

S. J. Hensel, 773-42A

TIM, 703-43A

August 18, 1993

TO: $\quad$ M. J. Plodinec, 773-A

S. L. Marra, 7()4-15S

FROM: $\quad$ B. J. Hardy, 773-64A B.jff

SUBJECT: Task Plan for Temperatures in the DWPF Glass Waste Storage Building

TASK PLAN:

TEMPERATURES IN DWPF GLASS WASTE STORAGE BUILDING

\section{MEMBERS OF TASK TEAM}

Task Leader: B. J. Hardy (SRTC/DWPT)

Others: $\quad$ S. J. Hensel (SRTC/SCS)

J. W. Jerrell (SRTC/SCS)

G. J. Hutchens (SRTC/NES)

\section{INTRODUCTION}

The Bechtel National, Inc. Detailed Design Instructions for Structural Design (DDI-02) requires that concrete components of the GWSB not exceed $150^{\circ} \mathrm{F}$ for structural elements and $200^{\circ} \mathrm{F}$ locally over a 24 hour period. ' In addition, the Waste Acceptance Product Specifications (WAPS) sets the maximum post cooldown temperature of the glass wasteform at $400{ }^{\circ} \mathrm{C}^{2}$ Various scenarios can be postulated which result in elevated glass and concrete temperatures in the GWSB. Therefore, it is important to determine the concrete and glass temperatures during both normal and off-normal conditions. 
The DWPF must certify that glass temperatures do not exceed $400^{\circ} \mathrm{C}$ after cooldown. However, because there are no means for making direct measurements of the glass temperature in either the GWSB or the DWPF during production, an analytical model is required. The analytical model must accurately predict (or at least bound) glass temperatures after cooldown has occurred. The post-cooldown temperature is dependent on the initial temperature profile in the glass which, in turn, depends on heat transfer from the time the pour is initiated through solidification. The post-cooldown glass temperatures must be calculated for the canister during transport, interim storage and shipment to a permanent repository. Further, the WAPS prohibits the presence of liquid water in the canisters. Therefore, the potential for condensation in the canister over a range of temperatures must be addressed.

This document details specific tasks required to develop a technically defensible and verifiable methodology for determining maximum temperatures for the waste-forms and the GWSB concrete structures. All models used in this analysis will satisfy Quality Assurance requirements and be defensible to review and oversight committees.

\section{CUSTOMER}

The customer for this task is the DWPF Waste Compliance Group, who will include applicable results of this task in the Waste Form Qualification Report. Other interested parties include DWPF Process Engineering and DWPF Cognizant Engineering.

\section{MODELING TECHNIQUES}

The modeling of glass waste-form and GWSB concrete ternperatures naturally separates into two parts: (1) the modeling of external conditions for the waste-forms or concrete; and (2) the modeling of the internal heat transfer processes. If the external conditions are sufficiently simple, analytical calculations or an estimate will suffice. However, more complicated external conditions, such as detailed convection in the GWSB or DWPF, will require the use of computer codes. Codes capable of accurately predicting air-flow in the GWSB and the DWPF are not presently on site and will have to be acquired. Given the boundary conditions, the steady state temperature profiles in filled canisters can be calculated with codes available onsite.

The maximum anticipated waste-form heat generation rate for glass going to Glass Waste Storage Building \#1 (GWSB \#1) is assumed to be such that the total canister power is 460 watts and the maximum anticipated gamma emissions are such that the dose rate is $5000 \mathrm{rad} / \mathrm{hr}$ at $1 \mathrm{ft}$ in air. Perturbations about these values will be made when more details about the waste-form composition are known. The uniformity of isotopic material in the waste-form will affect the distribution of the power density in the glass, which will affect the temperature distribution in the glass. Initially the power density will be assumed uniform and the effects of perturbations from uniformity will be investigated. If 
the perturbations prove to give significant variations in the glass temperature distribution, more realistic distributions of power density will be applied.

Given the boundary conditions, the temperature profiles within a filled waste-form can be calculated with codes available onsite. However, there are no codes capable of performing heat transfer calculations for a canister which is being filled. Modeling of a canister in the process of being filled with glass will be accomplished by writing a code, by applying existing codes to a quasi-steady filling process (if possible) or by acquiring a code suitable for modeling heat transfer from a moving boundary.

This task will satisfy the requirements of Reference 3 . The calculations made in this study will be reviewed independently and, when possible, compared to experimental data. The software will be validated against established models, alternative analytical calculations or experimental data (if available).

\section{Ob,ECTIVES AND PROCEDURES}

The objectives of this task and the procedures used to meet them are described below. In each part of the task, the work necessary to satisfy the task requirements is described first and additional work is described second.

1. Calculate the steady-state temperature profiles for free standing DWPF canistered waste-forms.

The temperature of the glass in a filled canister will be modeled for different ambient conditions with existing codes (e.g. P/THERMAL or FIDAP). For all cases conservative (nattural convective) boundary conditions will be assumed or will be calculated with a convection code. Glass temperature profiles will be calculated for a variety of heat generation rates, up to three times higher than the maximum anticipated for GWSB \#1. The ambient temperature will be varied from 0 to $100^{\circ} \mathrm{F}$. These results will be included in the Waste Qualification Report (WQR).

As additional work, if time and resources permit, a scoping analysis will be performed to determine whether it is necessary to model the filling of the canisters to obtain initial temperature protiles. No codes capable of modeling heat transfer in a material with a moving boundary are currently available onsite. Therefore, to model heat transfer for a canister which is being filled a code will need to be obtained or developed. Alternatively, it may be possible to model heat transfer during the filling of a canister with a cuasi-steady analysis based on available codes.

2. Glass temperatures for canistered waste-forms in the insulated storage racks and in the Shielded Canister Transporter (SCT).

Canisters will be located in the insulated storage racks and the SCT for finite intervals of time. Therefore, the transient glass temperatures will be of interest. Normal and 
off-normal ambient conditions will be identified for the insulated storage racks and for the transport of canisters in the SCT. These conditions will be used to calculate transient glass temperatures for the canisters while they are in these locations. Also the long time equilibrium glass temperatures will be calculated.

3. The maximum glass temperature for canistered waste-forms stored in the GWSB for various GWSB operating conditions and off-normal modes.

GWSB nominal operating conditions and postulated off-normal conditions will be identified. The operating conditions will be used to estimate limiting GWSB airflows which will be used to determine conservative convective boundary conditions for the waste-forms. The significance of radiative heat transfer must be addressed in evaluating canister boundary conditions. If thermal radiation is significant, it must also be included as a boundary condition for the waste-form. Radiative heat transfer calculations can be performed with onsite codes such as P/THERMAL. Gamma energy deposition from neighboring waste-forms may contribute significantly to the heat generation rate in the canisters. The gamma energy deposition calculations will be performed by using either a numerical model or by bounding with analytical calculations. When the boundary conditions for the canisters and the internal heat generation rates have been obtained, the glass temperatures can be determined with a code such as P/THERMAL or FIDAP.

The heat transfer calculations will be transient in nature and will include the glass temperature response if all GWSB air-flow is lost. The modeling will be performed for ambient air temperatures ranging from 0 to $100^{\circ} \mathrm{F}$ and glass power densities up to 3 times the maximum anticipated value. These results will be included in the WQR.

The use of limiting conditions, based on intuitive assumptions, may result in excessively conservative restrictions on DWPF/GWSB operation. Additionally, it is necessary to quantify the level of conservatism in "limiting" assumptions. Therefore, if time and resources permit, the GWSB operating conditions will be used to calculate detailed convective boundary conditions for the canisters. The detailed convection calculations will be compared with the limiting air-flows used in the convective boundary conditions for the canisters and will be applied as boundary conditions for the waste-form heat transfer calculations discussed above. Currently there are no codes available onsite which can be used to model air-flow in the GWSB. Hence, a detailed air-flow model will require the procurement of a commercial code. With the best commercial codes available, a substantial amount of time (more than a year at full time) will be required for a detailed and defensible model of the air-flow in the GWSB. Additional time will be required to acquire the code and to validate it according to Quality Assurance standards. 
4. The maximum concrete temperatures in the GWSB under various operating conditions.

Convection plays the most significant role in heat transfer to the concrete. Limiting GWSB air-flows, based on postulated GWSB operating conditions, will be used as convective boundary conditions. The disadvantages of the use of a limiting model are the same as described in 3 above. In addition to convective heat transfer, radiative heat transfer will also will also be a boundary condition on the concrete. The significance of radiative heat transfer must be addressed in evaluating the concrete boundary conditions. If thermal radiation is significant, it must also be addressed as a boundary condition for the concrete. Radiative heat transfer calculations can be performed with onsite codes such as P/THERMAL. The concrete will have an internal heat source due to gamma absorption. Preliminary calculations show that the gamma energy deposition does not make a great contribution to the heat transfer process, but should be included. ${ }^{4}$ Once the boundary conditions and the internal heat generation rates have been established, the calculations for heat conduction in the GWSB concrete can be performed. The heat conduction calculations will be made with the P/THERMAL or the FIDAP code.

If time and resources permit, detailed air-flow calculations will be performed. As discussed in 3 of this section, the calculations will require the use of a commercial code. The detailed air-flow calculations will be compared with the limiting air-flow calculations and the concrete temperatures will be evaluated. The difficulties associated with detailed air-flow calculations are the same as for 3 in this section.

5. Calculate the range of ambient air temperatures and heat generation rates for which condensation will occur in the canisters.

If ambient temperatures are sufficiently low the gas in the canister head space will reach the dewpoint temperature for water vapor. Because it is not permissible to have liquid water in the canister, calculations will be performed to determine the conditions under which condensation may occur, and whether it is a realistic possibility.

The dewpoint is a function of the pressure and concentration of water vapor in the head space. The initial gas temperature in the head space at the time that the canisters are sealed will be accounted for in the calculations. The gas temperature will be computed from the ambient air temperature, the internal heat generation rate in the canister and an assumed convective heat transfer rate at the canister surface by using a code such as P/THERMAL or FIDAP. Condensation calculations will be made for a range of glass power densities and ambient temperatures. A curve will be fit to the dewpoint conditions for future referenze. These results will be included in the WQR.

6. Perform calculations to determine optimal canister loading patterns in the GWSB. The canisters loaded into the GWSB will have different heat generation rates. Further, as the GWSB is loaded the air-flow paths and the distribution of gamma 
radiation will change. This implies that canister loading patterns and sequential loading procedures for the GWSB may result in significant differences in concrete and glass temperatures. An optimal loading pattern would be one which ensures that hoth glass and concrete temperatures are kept to a minimum for the various postulated GWSB operating conditions.

The effect of canister loading patterns on concrete and glass temperatures will be very sensitive to convection. Therefore, detailed convection models for the GWSB will be required. As noted in 3 above, modeling convection in the GWSB will require the acquisition and implementation of a commercial code. Because the acquisition and implementation of a commercial code will be difficult, and because the GWSB model itself will require a substantial amount of time, the optimal loading pattern calculations will be performed as time and resources permit. Thermal and gamma radiation will become more significant as the number of canisters increases and must be included in optimal loading calculations. If the code used to model convection in the GWSB is capable of performing coupled heat transfer calculations it can also be used to obtain the maximum concrete and glass temperatures. Otherwise, maximum temperatures will be calculated with a heat conduction code by supplying the boundary conditions obtained from the convection code.

The loading patterns will be varied and a sensitivity study on glass and concrete temperatures will be performed to determine the optimal loading pattern and sequence for canisters in the GWSB. These calculations will be performed for a variety of postulated GWSB conditions and canister power densities.

\section{KEY ITEMS TO BE CONTROLLED}

The key items to be controlled in this task and the means of control are as follows:

1. Software. Procedure Manual L13.1 does not provide details for the control of the level of software required for this task. ${ }^{5}$ Because more extensive software controls are provided in Procedure Manual 1Q34 these controls will be applied. ${ }^{6}$ Further software controls required for essential software as specified in the WAPS ${ }^{2}$ will be implemented.

2. Laboratory notebooks. Laboratory notebooks will be controlled as per procedure GTQA-2-7 in the Procedure Manual L13.1. ${ }^{5}$

3. Modeling assumptions and GWSB specifications. This data will be controlled by having the data technically reviewed.

4. A records package will be developed for this effort, which will conform to GT-QA17-2 in the Procedure Manual L13.1. ${ }^{5}$ 


\section{DELIVERABLES}

The deliverables of this task will be:

1. A report containing the results of the analysis described in the Objectives and Procedures Section. The report will include the following:

i. The detiils of the normal and off-normal conditions which were modeled in this study.

ii. The maximum heat generation rate in the glass, constant for all canisters, such that the concrete temperature limits are not exceeded under normal and postulated off-normal operating conditions.

iii. The maximum heat generation rate in the glass, constant for all canisters, such that the glass temperature limits are not exceeded under normal and postulated off-normal operating conditions.

iv. The maximum number of canisters, at differing power levels, that can be loaded into the GWSB without exceeding the glass or concrete temperature limits.

$v$. The maximum power levels for canisters in the SCT and the insulated storage racks.

vi. Recommendations for canister loading into storage positions to prevent the occurrence of "hot spots" which may cause the glass or concrete temperature limits to be exceeded.

The report does not include an analysis of the Time Temperature Transformation (TTT) diagranıs, which will be covered by other work.

2. A description of software used in this task and its potential for use in calculations for the current Glass Waste Storage Building and in the design of future buildings.

3. The maintenance of the software in 2 of this section as "Essential Software" by the Glass Technology Group in accordance with the requirements of Reference 2.

\section{REFERENCES}

1. DDI-(22, Bechtel National Inc. Detailed Design Instructions for Structural Design for the Defense Waste Processing Facility and New Waste Transfer Facility. Bechtel Document, Rev. 6, August 6, 1985.

2. Office of Environmental Restoration and Waste Management. Waste Acceptance Product Specifications for Vitrified High-Level Waste Forms. USDOE Document EM-WAPS , Rev. (), U. S. Department of Energy, Germantown, MD (1993).

3. M. J. Plodinec, S. L. Marra. Task Assignment: Temperatures in DWPF Glass Waste Storage Building. Westinghouse Savannah River Company document, WSRC-RP. 93-845 (1993). 
4. B. J. Hardy, S. J. Hensel. Peaking Factors for Loading Floor Temperatures in the GWSB. Westinghouse Savannah River Company Document, SR'T-GTC-93-())68 (1993).

5. Glass Technology Procedures Manual. Westinghouse Savannah River Company Procedure Manual L 13.1, Rev. 31 (1993).

6. Nuclear Reactor Technology and Scientific Computations Quality Assurance Manual. Westinghouse Savannah River Company Procedure Manual 1Q-34 (1991). 


\section{APPROVALS:}

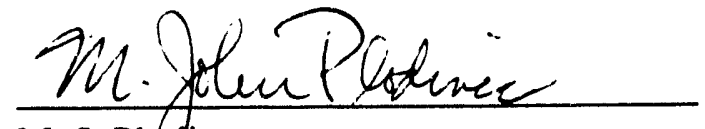

M. J. Plodinec

Manager, GTG

Sulfietophecte

E. W. Holtzscheiter

Manager, DWPT

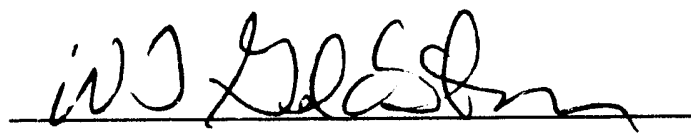

W. T. Goldston

Manager, DWPF Regulatory

Compliance

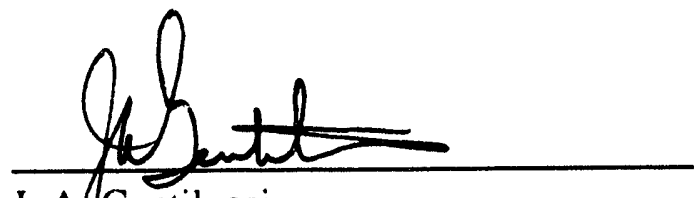

J. A/Gentilucci

Mafager, DWPF Process

Engineering

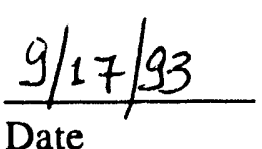

Date

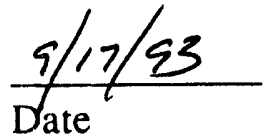

9/29/a3

Date

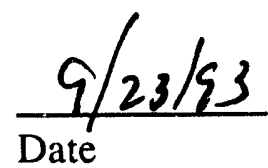


GLASS TECHNOLOGY TASK CONTROL MATRIX

KEY ELEMENTS

\begin{tabular}{|c|c|c|c|c|c|c|c|c|c|c|c|c|}
\hline 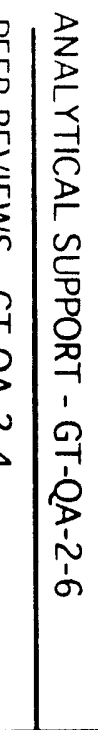 & 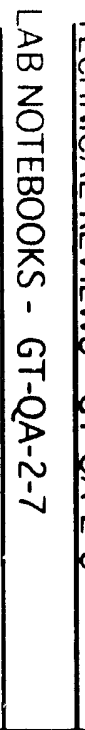 & 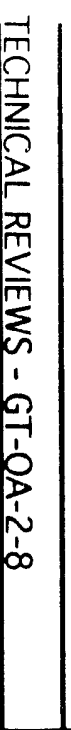 & 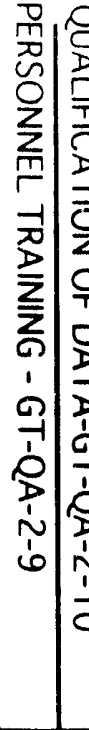 & 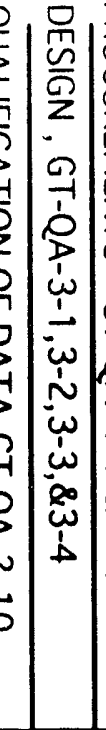 & 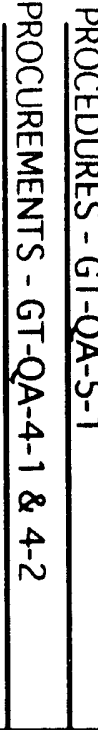 & 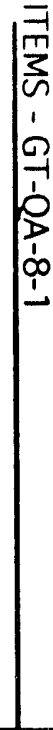 & 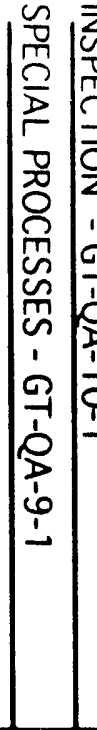 & 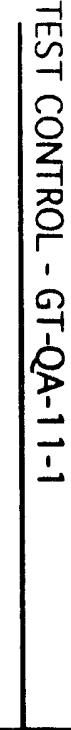 & 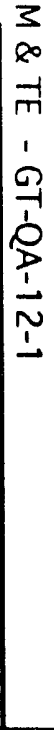 & 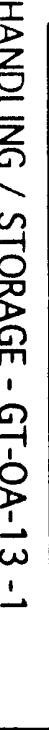 & & 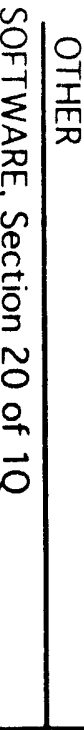 \\
\hline & $x$ & $\mathrm{x}$ & & & & & & & & & & \\
\hline & & $x$ & & & & & & & & & & \\
\hline & $x$ & $x \mid$ & $x$ & & & & & & & & & X \\
\hline
\end{tabular}

Numerical/Analytical Models

Input Data
Software

All activities are subject to the requirements of GT-QA-1-1, 1-2, 6-1, 6-3,

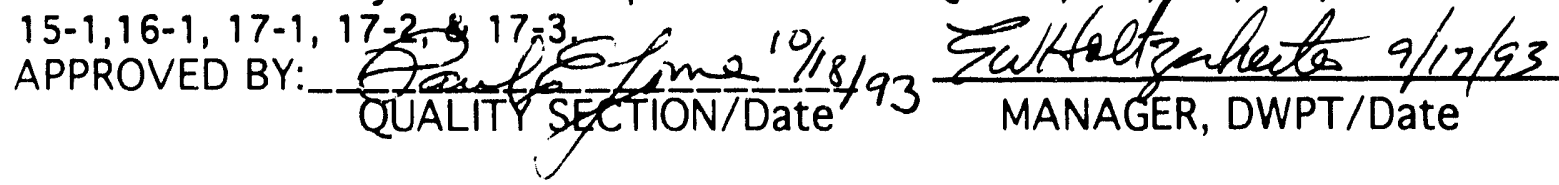



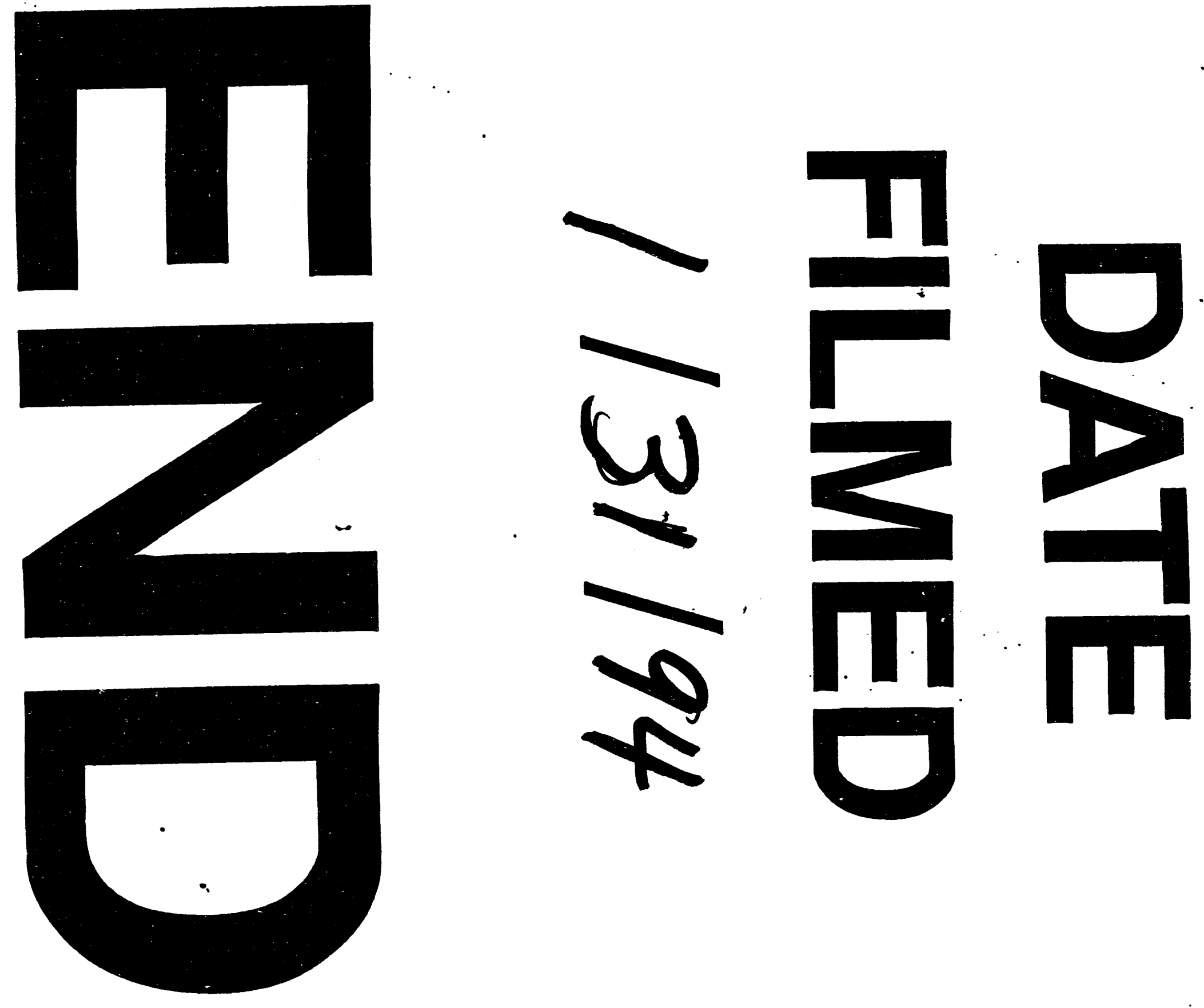


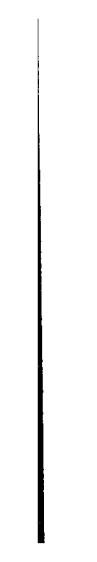

